\title{
Illusionary safe havens: The role of the city and the country in Zelda Lockhart's Fifth Born and Fifth Born II: The Hundredth Turtle
}

\begin{abstract}
Fifth Born and Fifth Born II: The Hundredth Turtle, written by the African-American author Zelda Lockhart, create a duology whose characters make many physical and spiritual journeys. In the story whose setting alternates between St. Louis, New York, and rural Mississippi, the city and rural areas both seem to be treated as a potential safe haven from the secrets and violence created and cultivated by the other place. This article explores the correlation between geography and emotion in Zelda Lockhart's Fifth Born duology. Beginning with sketching an outline of the historical context of the idea of city versus non-city in African American literature, and then briefly illustrating the notion of Emotional Geographies, the article explores the role which the city and the country play in connection with the characters' abuse, focusing specifically on sexual violence.
\end{abstract}

Keywords: emotional geographies, city, country, abuse, sexual violence, African American literature, Zelda Lockhart, Fifth Born.

Geography in its universal understanding can be defined as "the scientific study of the earth's surface, physical features, divisions, products, population, etc.[sic]” (Hornby \&Turnbull 2010: 647). This definition aligns itself with the idea of dividing places into city and non-city areas. However, scientific research has reached the point where basic definitions are no longer enough to comprehend the surrounding world; therefore, researchers have been broadening existing definitions and putting forward new notions, one of which is the idea of Emotional Geographies. Liz Bondi, Joyce Davidson, and Mick Smith explain: "An emotional geography ... attempts to understand emotion - experientially and conceptually - in terms of its socio-spatial mediation and

1 Address for correspondence: The Faculty of Philology, University of Białystok, Pl. NZS 1, 15-420 Białystok, Poland. E-mail: magdalena.lapinska.91@gmail.com 
articulation rather than as entirely interiorised subjective mental states" (2007: 3, italics in original). This article explores the abovementioned correlation between geography and emotion in Zelda Lockhart's Fifth Born and Fifth Born II: The Hundredth Turtle. The article attempts to illustrate the connection of the city and the country to the characters' abuse, with the role of urban and non-urban areas in African American literature being briefly outlined. Consequently, the article offers a short introduction to the theory of Emotional Geographies, which provides a link between geographical spaces and emotions. Subsequently, the article focuses on the significance of the main character's repeated escapes from the city and her shifting perception of the city and the country. The abuse the characters suffered is analyzed in light of the role that the city and the countryside play at certain points in the story. The analysis provides an illustration of the view that Zelda Lockhart seems somewhat to rebel against the traditional roles of urban and rural areas in African American literature.

Zelda Lockhart is not only an African American writer but also a director at Her Story Garden studio and a publisher at La Venson Press, occupations in which she attempts to help women manage their hardships and struggles through sharing their stories. The Fifth Born duology tells such a story, as it presents the hardships that Odessa Blackburn faces throughout her life: from the violence she experiences as a little African American girl to the emotional struggles she endures as a grown woman, Lockhart leaves her own mark on one of the prevailing themes of African American women's literature, namely that of family violence. The theme can be found amongst writing of many African American novelists, such as Toni Morrison's The Bluest Eye, Alice Walker's The Color Purple and Bernice L. McFadden's The Warmest December. Although parallels can be drawn, especially between The Bluest Eye and Fifth Born (the first installment of the duology), each explores the theme in its own unique way.

Yoshinobu Hakutani and Robert Butler point out that the notion of the urban versus the non-urban setting has a very rich history in both American and African American literature:

While one of the central drives in our classic literature has been a nearly reflexive desire to move away from the complexity and supposed corruption of cities toward idealized nonurban settings such as Cooper's West, Thoreau's woods, Melville's seas, Whitman's open road, and Twain's river, very often the opposite has been true in African American letters. (1995: 9)

In Fifth Born II, Odessa moves to the country where she finds temporary peace. However, she yearns to live in a place full of possibilities, free from the ghosts of a traumatic past, which her life in the country does not provide in the long run. Her subsequent return to the city to study at university and live with her son; Lamont's move to New York; and even Ella Mae's short attempt to live in the city, all seem to support the 
abovementioned notion that "the main tradition of black American literature has been persistently pro-urban in vision" (Hakutani \& Butler 1995: 9). The history of slavery suffered by African Americans seems to be the predominant influence of a more negative attitude towards non-city areas; a perspective that can trace its roots to the fact that the institution of slavery was exceptionally strong in the non-urban South with its cotton plantations. As Hakutani and Butler remind us, even

[i]n the era following the literal end of slavery, new strategies for reinslavement were devised in the South where codes of segregation and the practice of sharecropping were to make it impossible for black people to establish a positive image of rural life which could serve as a counterbalance to the pull of the cities. (1995: 11)

Although the city has been a vital symbol in African American literature, if a piece of literature were to reflect the entirety of black experience, rural areas would need to play as important a role as the urban sites because as Priscilla R. Ramsey emphasizes:

From the earliest historical contact with the new world,[sic] black experience has been both agrarian and economically oppressed in nature. Only with the mass migration of late nineteenth century and early twentieth century did the character of black experience evolve into one of predominantly urban character.[sic] (1995: 225)

Changes in setting between city and non-city areas presented in the Fifth Born duology coincide with important events in characters' lives; thereby, suggesting vital roles of urban and rural landscapes in shaping the African American identity.

The idea of Emotional Geographies is a well-suited theory for the analysis of the Fifth Born duology because the change of the geographical settings either cause or result in the emotional shifts the characters undergo. Bondi, Davidson, and Smith explain that:

the emotional geographies of our lives are dynamic, transformed by our procession through childhood, adolescence, middle and old age, and by more immediately destabilising events such as birth or bereavement, or the start or end of a relationship. Whether joyful, heartbreaking or numbing, emotion has the power to transform the shape of our lives, expanding or contracting our horizons, creating new fissures or fixtures we never expected to find. (2007: 1)

The abovementioned emotional situations not only shape how one will experience future situations, but as Deborah Thien claims: "shifting interpersonal and community spaces of intimacy have varying consequences for people's sense of emotional wellbeing" (2007: 192). The places where one interacts with other people matter when it 
comes to building communities or personal relationships because one comes to remember not only people but also the setting of the significant events in one's life.

Bondi, Davidson, and Smith postulate that "[t]hrough memory - conscious and unconscious, psychic and somatic - we all carry traces of past geographies, in ways that are always emotionally coloured in hues ranging from pale to vivid" (2007: 12). The strength of emotional experiences appears to influence the vividness of the memory of places. Furthermore, one could assume that in some instances the emotional highs would take over one's memory, thus blurring the background and erasing its details as well as simultaneously forging strong links between particular emotions and a given place. The interrelatedness of emotions and places, as well as the incorporation of past geographies into oneself, is represented in Lockhart's novels.

The duology is filled with journeys between urban and rural areas. At the beginning of Fifth Born the narrator informs the readers that the Blackburn family frequently visits grandparents in the country:

Mama said we were likely to tear a hole in the road as much as we went back and forth between Mississippi and St. Louis. Every summer, without fail, we took the highway south, the road thumped beneath us, and wires looped from pole to pole, landing us in a different reality, where The Howdy Doody Show was the only thing to watch on TV, and the sound of cicadas and crickets replaced the sound of traffic. (Lockhart 2002: 9)

This annual trip signifies something different to Odessa than it does for the rest of her family. Her parents and siblings treat the holidays as an escape from the city, the time when they can relax and have fun. For Odessa, however, it is a reprieve from the violence she experiences when the whole family is at home in the city. The rural area becomes a temporary safe haven where she is finally free to behave like a child, which she is unable to normally do because of the responsibilities thrust upon her coupled with the violent acts of her parents. "From my hiding place, I watched Mama do the job she had left me to do at home-bathe the boys, feed them, stare at them from the front porch. She kept one eye on the boys and one eye on Grandeddy, who might be looking at how wonderful a mother she was" (Lockhart 2002: 144). In Father-Daughter Incest Judith Herman and Lisa Hirschman call attention to the fact that the described transference of duties from mother to daughter is not uncommon when incest occurs:

It has frequently been observed that the mother in incestuous families is ill, incapacitated, or for some reason emotionally unavailable to her husband and children. The families adapt to this stressful situation by reassigning many of the mother's traditional obligations to the oldest daughter. The family may come to rely on this daughter for a large part of the housework and child care and for emotional support and comfort. (2000: 45) 
However, in the novels under scrutiny here it is not the eldest daughter who is most burdened with the mother's role, but Odessa - the 'fifth born' who is not the mother Bernice's biological child. This could point to the fact that Bernice may perceive Odessa as the source of the abuse happening in their home and the mother's way of punishing Odessa is to shift all the troublesome burdens onto the girl. Bernice's punishment would have probably continued during the family's vacations in the countryside if it were not for the fact that it was the grandmother who had entrusted Odessa to Bernice upon the child's birth. The grandparents' watchful eye meant that Loni and Bernice could not behave in the same manner as they did in the city. Therefore, during the holidays, the parents pretended to be someone else, attempting to present a picture of a perfect family; whereas, when they returned home to the city, Odessa's life would revert to its bleak reality filled with violence and neglect.

In his essay on the Life and Times of Frederic Douglas, Robert Butler remarks: "The city here is a liberating world because it not only separates the hero from a restrictive past dominated by an "old master" but also gives him the fluid, indeterminate space he needs to define himself in fresh terms" (1995: 27). Butler's observations of the city's significance in Douglas's writing can be applied to Lockhart's work; however, in the Fifth Born duology it is the countryside that possesses the majority of liberating forces for Odessa. Her move from the city to the country, which occurs at the end of the first novel, aligns itself with the idea of freeing herself from the "old master". Unquestionably, Odessa seeks an escape from the violence that permeates her life in the city where her master is her abuser. Both the mother and the father are abusive towards Odessa in their own unique ways; therefore, one cannot indisputably discern which parent should be perceived as the master the girl wants to escape from. I would argue that the parents taken together can be attributed the shared role of 'an ultimate master', a figure whose domination reaches all aspects of one's life, which in turn is an image reminiscent of the power the owner had over his slave in the past. A stark parallel can be drawn here because Odessa's parents have complete control over how her life develops. Odessa's first rape experience shatters the fundamental trust a child has for those closest to them. A father's violation and a mother's anger and denial, combined with the subsequent abuse from both parents are clear indicators that it is parents' dominance exerted in their city home that Odessa flees from. She attempts to find space in the country to discover who she is away from the toxic relationships formed in the city because the rural area is the only place where the abuse ceases, at least for a time, during the holidays at the grandparents' home. The visits provide Odessa with a temporary safe haven. According to Simon Schema, landscapes are created in the mind before they are ever experienced by the senses (1995: 6-7). The influence of mind and memory in an individual's experience of landscape can, to some degree, be noticed in the novels being discussed here. For example, Odessa's perception of the country as a tranquil place is 
not connected with the natural aspect of the place, but rather with the memories of the grandmother and the safety she provided. In his exploration of the notion of landscape and memory, Schema contemplates: "if a child's vision of nature can already be loaded with complicating memories, myths, and meanings, how much more elaborately wrought is the frame through which our adult eyes survey the landscape" (1995: 6). When considered, it can be discerned that Odessa's traumatic experiences during her childhood caused her to perceive landscapes through a thicker emotional fog than many adults would normally experience, given a lack of abuse in their personal history or having been witnesses of violence. The emotional distortions of her perspective seem to shift the city and the country from their geographical meaning to the contrasting emotional landscapes of peril and safety. When Odessa is still a little girl her grandmother dies and the family trips become much less frequent. Consequently, Odessa loses her temporary safe haven, a place where adults love you instead of hurt you.

In time, Odessa reclaims her safe haven and has space to redefine herself once she decides to move to the country. She comes to her decision after learning that her own conception was the result of her father Loni's rape of Ella Mae, her estranged and ostracized aunt:

In Ella Mae's garden, my mind did not race with wondering about home, with replaying things Mama and Deddy had done or said. In the garden I heard the warm, thick breeze whisper, heard the occasional slither of a lizard or a copperhead through the dry grass around the garden, felt the sun on my skin. ... I was there under the sky without the noise of voices, and the silence was intoxicating. The grief had slipped away to a manageable place, even though only two months before, the grief of losing my siblings had been tangled around new home and new mother[sic] like the choking honeysuckle vine. (Lockhart 2010: 18)

It seems that the combination of the safety provided by Ella Mae and the tranquility of the country allows Odessa to fully breathe, to regain balance, and with time, to start her life anew. Odessa faces her problems and lives through emotions such as grief, in order to be able to move on with her life. She chooses to accept the past events for what they were, unlike her mother Bernice who is rarely able to acknowledge that a bad situation had taken place.

It would seem that Bernice's view of life is strongly rooted in denial as she frequently alters the real stories of uncomfortable truths so that they do not cause her any discomfort in the present and the future:

'Folks bury the things they don't want to be lookin at inside they heads. They just find some kind of way to wipe it away or kill it so they can keep on surviving the best they can.'(...) 'Mama always changes stuff she doesn't want to think about. I mean, she doesn't want to 
deal with it. So it's like all of a sudden she goes from talking and laughing and being Mama, to not being able to see, or hear. Then all the craziness around her gets turned into one of her stories about the good times.' (Lockhart 2002: 158)

Bernice attempts not only to deny her feelings about certain situations but to literally deny reality by re-shaping the truth. However, not everything can be hidden behind false words. Some actions produce consequences which cannot be erased. Nevertheless, in Odessa's family if something cannot be erased it must therefore be hidden. In these novels, the city and the country function as hiding places for unwanted truths. Ella Mae is hidden in the country. She lives apart from the rest of the country folk and does not maintain contact with her family. Although she was never truly close with her relatives, the distance, both physical and emotional, that now separates them is the result of violence and lies. When she was raped, her mother attempted to hide the truth by denying that the rape occurred, the very actions which Bernice later mirrored. "Then she said to me, 'Loni and Bernice and them kids left here yesterday. Now you know ain't he or nobody else been up to where you stayin. You know better than to say that. You got to let the devil stop having your soul. On Sunday you gonna go get baptized down at the river"' (Lockhart 2002: 190). When Ella Mae learnt that the rape had resulted in her pregnancy, she found a secluded place and built herself a home where she planned to raise her child, the child she loved despite its origin. After a difficult labor, her mother lied to her and claimed that the child had been stillborn. Ella Mae did not fully believe the claims. "Nothin was mine in this world. Motha and them wasn't gonna even let me have my baby. They had done killed it or let it die" (Lockhart 2002: 195). This deepened the already existing rift between Ella Mae and her family. The fact that Ella Mae's child was hidden away in the city amongst Bernice's children resulted in the family perpetuating the lie once told and did not allow for attempts to heal the rift. Sending Odessa to the city meant putting space between the lies and the truth, not only emotionally through cutting family ties but also literally through geographical distance. However, Ella Mae does not distance herself from her pain. She has lived in the country her whole life and despite her attempt to leave, she could not permanently relocate to the city. In spite of all the trauma she had experienced in the country, this place is marked with strong contrasting emotions because she had also experienced brief instances of happiness. Ella Mae's countryside is like a mine field. She has to tread carefully in order not to touch anything that would trigger an explosion of memories tarnished with traumatic events. She manages to survive for a long time without any explosions of emotions until Odessa detonates her own bombshell by revealing her abuse. Odessa's revelations seem to trigger an onslaught of memories from Ella Mae's terrible past and the violations committed in the city and the country merge to tell a complete story of one family's past filled with violence and lies. 
The author uses physical space as a metaphor for emotional distance and the act of wandering seems to symbolize the passage of time because Odessa's exploration of the country leads her to discover the truth about her parentage and subsequently leads to the abovementioned fusion of Loni's violent acts committed in the country and in the city:

By the time I was twelve years old, I didn't feel human any more; just felt like a raw thing bobbing around in that sea, hoping for touch. Then, on the thirteenth summer vacation to Grandeddy's, some combination of my hurt, my need for 'Mama,' and my need to survive sent me wandering off Granddeddy's land, into the field, then another, until there was no way to go back without being beaten, and no way to stay where the open land could not hide me. In that space between the lie told thirteen years before and the land that borne witness to four generations of my family's pain, I bent down to hold my ashy ankles and cry, and I found myself coiled up in my real mother's yard, all the while thinking she was just a long lost aunt. (Lockhart 2010: 5)

Odessa learns not only of the circumstances of her conception but also that the grandmother whom she loved deeply had placed her in the hands of people who inflicted unimaginable harm on her. Odessa's grandmother justified her actions once she was confronted by her daughter Ella Mae:

I done did the best I could. I been scared in this world too. There's pains I live with every day that you don't know nothing about. I try to send your baby away out of this life that I been livin, out of this life you been livin. Ain't no use for me no more. It was the best thing to do to leave you where the devil had already took you, and to do what was best for your child. (Lockhart 2002: 199)

The grandmother clearly connects the country with the hardships both she and Ella Mae experienced; therefore, she wanted to give her granddaughter the chance for a better life in a different place. In an analysis of Toni Morrison's Jazz, Anne Whitehead states that "the City shapes and is shaped by people's behaviour and it acts metaphorically as a site for the renegotiation of morality, lifestyles and familial patterns" (2004: 149). One could argue that the grandmother in Lockhart's story also sees the city as a place where the familial patterns could be disrupted and she hopes that the beginning of a generational cycle of children born out of rape can be halted by sending Odessa to the city, far from the place where the abuse has its origins. Despite Grandmother's good intentions, Odessa does not have a happy life because the sexual predator of this story travels between the city and the country freely and his violence is not contained to one place.

Ella Mae and Odessa are connected not only by their blood and the fact that Loni raped both of them: mother and daughter. They were also both born out of rape, which 
points to the abovementioned beginning of a generational pattern. The grandmother did achieve a measure of success in that Odessa'a child is not born out of rape, but she did not prevent Odessa herself from becoming a victim of rape. Rape and incest is what binds Ella Mae and Odessa so strongly:

Ella Mae was considered the crazy heathen in our family because she was born out of her Indian grandfather's rape of her mother. Rape and incest weave themselves around the pains of my life tighter than the weave in Ella Mae's rag rugs. What looks like a confusion of discarded, discolored old clothes up close is really a landscape once you get some distance. (Lockhart 2010: 3)

The author compares emotional turmoil to a landscape and if one would try to imagine it, they would probably see uneven terrain, steep hills and winding rocky roads due to all the problems both women encounter. However, even though the past did not provide the women with the sound ground to walk through their paths of life, eventually they manage to find a place and people they can call home: their safe havens.

Although Odessa suffers physical and emotional abuse from both of her parents, sexualized violence seems to link the city and the country in Lockhart's duology. The perception of sexual violence has changed throughout history, as B.J. Cling explains:

These types of what we now feel are "wrongs" seem to be part of the fabric of human society and to date as far back as there are records of human behavior. It appears that none of them were viewed as crimes against women or children until relatively recently. Thus, sex with a woman without her permission, and physical harm to a wife or a child, were apparently viewed as part of a man's allowable relationships. (2004: 7)

Sexual abuse amongst African Americans, especially historically, has its links to the institution of slavery. During slavery, the master owned black people and could do anything he wanted to them, thus his violations were not questioned. However, violating slaves without their owner's permission was against the law, although it was considered a violation of property rather than a violation of a person. In her novels, Lockhart predominantly presents two types of sexual abuse: rape of adult women and rape of children. Diana E. H. Russel remarks on the distinctions between these two categories:

An adult woman is more likely to have experienced trust in intimate relationships, to have a sense of who she is and what sex is before the traumatic attack. In contrast, children's capacity to trust can be shattered. Their sense of who they are and what sex is about is often totally or substantially shaped by the sexually abusive experience. (1986: 157) 
Zelda Lockhart allows the readers to witness Odessa and Ella Mae's lives after their assaults. However, the fact that Ella Mae's rape was her first sexual experience and she was never romantically involved with anyone prior to Loni's violation seems to bring the impact of her experience closer to that of Odessa's. In light of Russel's observations, both women have to learn how to trust others and create intimate relationships without allowing Loni's violence to distort their future experiences. Even though Ella Mae and Odessa are not the only victims presented in the novels, their stories are explored in the most detail and they are pertinent to the link between the city and the country that the Blackburns and the Laceys created and cultivated.

Erna Olafson points out that, "In the Victorian era, there had been strong and effective efforts to protect children from physical abuse, sexual abuse, and neglect, public attention that carried over into the early years of the $20^{\text {th }}$ century and then, mysteriously, waned" (2004: 155). Lockhart's story takes place between the 1960s and 1980s, and Odessa's perils clearly mirror the notion remarked on by Olafson because nobody attempted to aid the little girl once the abuse begun. Odessa's abuse seems particularly damaging to the process of creating one's own self-image as she had no chance to experience an abuse-free life because she was raped by her father for the first time at the age of five. Odessa knows something wrong has happened but she does not fully comprehend the situation due to her young age. She attempts to share what happened with her mother, however, she is violently stopped:

She pulled the covers off, and her eyes darted around at the splotches of red that stained the sheets. Her face froze, a fork of wrinkles forming on her forehead. She bit her lip and never raised her eyes to look at me. I lay there, still shaking. My eyes begged for her to hold my stiff body. When she didn't say anything, I cried out loud, "Mama!" I called out her name over and over. Why wouldn't she touch me? Towanda said, "Don't touch the bird eggs in the backyard, because if you put your dirty hands on them, the mother will kick them out of her nest." When she looked at me, I could tell that behind her lips she was gritting her bottom teeth against her gold tooth. I wasn't sure what she was going to do, so I looked in her eyes and started telling her what happened. "Deddy, Deddy he came in here-" But looking in her eyes, I knew she had heard, she had heard me whimpering. She had heard because when one of us groaned with a fever, she came without waiting for us to call out, she just knew to come. "Shut up! You hear me?" Her big hand, still smelling like bleach from washing Benson's diapers, crashed down and stung my bruised thigh over and over, until everything went black again. (Lockhart 2002: 40-41)

Her mother's initial reaction is violent and what follows is her denial and re-shaping of the truth - a pattern which Odessa witnesses throughout her life. Everyone is informed that Odessa is sick, the father seems to have no recollection of his actions due 
to his intoxication and with time Odessa also forgets the "incident". Bernice's reaction created a probable reason for the shattered relationship between mother and daughter. Russel suggests that "[t]here is always the possibility that a poor relationship between a mother and daughter may improve later in their lives. But father-daughter incest makes this much less likely to occur" (1986: 385). Although Odessa forgets her first rape until she is sexually violated again, her mother is aware of the incestuous relations the whole time, and this influences the manner in which she treats her daughter. When Odessa is older she is raped by her father once again and with this act the memories of the first rape are triggered. "I remembered - like remembering to breathe when I was born I remembered Deddy's hand pushing my Nakie doll in between my five-year-old legs and ripping me" (Lockhart 2002: 110). This time, Odessa completely understands what has happened and no one can tell her differently as the memories do not fade away with time. The returning memories and the realization that her mother did nothing to stop Loni from being able to further hurt Odessa seem to permanently damage the already poor mother-daughter relationship.

Both of Odessa's rapes happen at home in the city; however, the rape which resulted in her conception had taken place in the country - the place which for the longest time during her childhood, she considered a safe haven. Ella Mae's rape in the country points to the notion that sexual violence occurs everywhere, even in places some consider to be void of violence. Russel notes that "[i]t is commonly believed that incestuous abuse occurs more frequently in rural areas" and that "[a] substantial amount of research confirms this belief" (1986: 113). Although the Fifth Born duology provides an example of incest in the country (the grandmother's relations with her own father resulted in the birth of Ella Mae), the incestuous relationship which is displayed in most detail and propels the events in the story, happens in the city. Incestuous acts seem to skip a generation because Ella Mae's sexual trauma is not connected to incest. No matter the place of the violence or its type, the traumatic experience and its results are concealed. As mentioned above, Odessa's grandmother attempted to hide her own daughter Ella Mae's rape and so did Bernice when Odessa's violation occurred. The fact that both mothers seemed to protect the perpetrator of violence at the expense of the victims may not only be a family's approach to dealing with sexual violence, but may also be historically motivated.

One of the stereotypes that emerged from slavery is that of a Jezebel - a promiscuous black woman. The mothers' silence presented in the Fifth Born duology may stem from not wanting to perpetuate this social stereotype. Moreover, during the Civil Rights Movement race and sexual violence were linked. Danielle L. McGuire calls attention to the fact that "[b]etween 1956 and 1959, sex and sexual violence sat at the centre of the freedom struggle, and African Americans deployed different strategies to carry the movement through a crucial and difficult transition, including testimony, armed 
self-defense, and international pressure" (2010: 137). Because of that, the silence of such mothers could be construed as socially mandated. Black men had to be perceived as non-threatening in order not to perpetuate the fears of whites that African American men would harm their women, therefore "[s]urvival sometimes required that silence surround sexual violence” (McGuire 2010: 137). Historical setting can, to some extent, explain the silent acquiescence of those who knew of the violations; however, morally speaking their actions should be questioned. In Telling Incest Janice Doane and Devon Hodges assert, "The African-American incest story, precisely because of the way it explicitly operates as a narrative that undoes boundaries and violates taboos, is a useful discursive strategy for opening up and reconceptualizing the dynamics of public power and private speechlessness" (2002: 33). As presented above, Lockhart's story clearly deals with the lack of vocal assertion where sexual abuse is concerned. However, this ends when Loni's two victims meet and share their common suffering. Once the painful and traumatic stories are finally voiced, Ella Mae and Odessa can begin to move on. The author seems to present the notion that in order for victims to restart their lives after the abuse, they need to have an outlet for their painful stories.

When discussing neglect as a form of family violence, Denise A. Hines and Kathleen Malley-Morrison differentiate emotional neglect, which they postulate "occurs when parents fail to attend to their child's basic emotional needs" (2005: 135). Both Odessa and Ella Mae wanted to be loved and protected by their mothers, however, neither of them was. When Ella Mae confesses that she was raped and her mother openly lies in response to the accusations, Ella Mae knows that maintaining the pretences of one big loving family is more important to her mother than her daughter's feelings. "About then, I looked in her eyes and knew that she done lied to me and herself, and I knew she wasn't gonna be able to love me no more" (Lockhart 2002: 190). When Odessa reveals her own sexual abuse to Ella Mae, the validity of the confession is not questioned. It seems that the shared experience helps the women believe their respective stories, or perhaps the author wishes to relay the idea that a real or true mother always believes and protects her child. Although sexual violence is not linked to one specific place, the aspects of the story connected with it come full circle: with the first rape having taken place in the country and the ultimate revelation of all the lies also happening in the country.

The concept of belonging to a place is also presented in the duology. Owain Jones claims that "remembering being-in-place, and perhaps remembering through place, through emotions of (remembered) place are powerful elements of emotional geographies of the self" (2007: 213). The idea that places become parts of a person is briefly explored in Fifth Born II. Ella Mae claims: "You cain't [sic] own a person or a thing in this world, so quit trying” (Lockhart 2010: 225). However, she also states: "Odessa, not all my spirit is in my body anymore. It done spread itself out around here, and I cain't take half 
of me away and leave the other half here" (Lockhart 2010: 225). Her views seem to point to the notion that whereas we cannot truly own things or places, but can only emotionally claim them and "carry" them with us, things and places can, in contrast, own parts of us. Odessa reflects on this idea. "Was all of my spirit in my body, or in Starkville and its history or back in St Louis, where the souls of my siblings scurried? Maybe behind the bricks of the house on Kennedy Avenue, the house I could never imagine entering again of fear of flashbacks that I would never escape" (Lockhart 2010: 226). It is clear to her that places evoke memories; for her, the city of St Louis in particular with all its hidden violence. However, the idea that she leaves parts of herself behind at the sites of her great emotional struggles seems slightly baffling to her. The novels show that the places we visit influence us because of the people we come into contact with there, but it remains unclear whether we have a reciprocal effect on these places. In Lockhart's story the characters seem to leave pieces of themselves in places where they experienced something traumatic. Due to the characters' traumas, it seems that their emotional landscapes become labyrinths - places one can easily get lost in and have difficulty exiting without help. In the novels the only way to exit the emotional labyrinth of trauma is to leave a piece of oneself behind and try to create a new life in a new place while attempting to incorporate the pieces one had no choice but to take with them.

The Fifth Born duology, to some extent, subverts the importance of the contrasting idea of the urban versus the non-urban so present in the canon of African American literature. The author seems to play with the perception of both places through shifting their meaning for the characters. The city and the country are contrasting emotional landscapes of peril and safety for the main character until the truth of a violent past emerges. Once the truth is no longer hidden, both the city and the country are tainted with the emotional residues of traumatic experiences. The safe haven in the form of the country is lost and the opposition between the city and countryside vanishes. The illusion of safety which Odessa relied on is gone and the main character turns to people, rather than places for comfort. Moreover, through the depiction of one abuser whose violence reaches across the borders of both the city and the country, the author pushes the reader to search for meaning in people rather than in places, because the characters' actions changed the perceptions of the landscape in the story. The city and the country play a vital role in the duology because they represent the notion that violence is not place-bound and that escaping from the place of trauma allows for only temporary reprieve, as true safe havens are provided by people and not geographical areas.

\section{References}

Bondi, L., Davidson, J. \& Smith, M. 2007. Introduction: Geography’s 'emotional turn'.

In: J. Davidson, L. Bondi \& M. Smith (eds.), Emotional Geographies, 1-16. Aldershot, England; Burlington, VT: Ashgate. 
Butler, R. 1995. The city as liberating space in life and times of Frederick Douglass. In: Y. Hakutani \& R. Butler (eds.), The City in African-American Literature, 21-36. Madison: London; Cranbury, NJ: Fairleigh Dickinson University Press; Associated University Presses.

Cling, B. J. 2004. Sexualized violence against women. In: B. J. Cling (ed.), Sexualized Violence against Women and Children: A Psychology and Law Perspective, 7-11. New York: Guilford Press.

Doane, J. L, \& Hodges, D. L. 2002. Telling Incest: Narratives of Dangerous Remembering from Stein to Sapphire. Ann Arbor: The University of Michigan Press.

Hakutani, Y, \& Butler, R. 1995. Introduction. In: Y. Hakutani \& R. Butler (eds.), The City in African-American Literature, 9-18. Madison: London; Cranbury, NJ: Fairleigh Dickinson University Press; Associated University Presses.

Herman, J. L., \& Hirschman, L. 2000. Father-Daughter Incest. Cambridge, Mass: Harvard University Press.

Hines, D. A., \& Malley-Morrison, K. 2005. Family Violence in the United States: Defining, Understanding, and Combating Abuse. Thousand Oaks: Sage Publications.

Hornby, A. S., \& Turnbull, J. 2010. Oxford Advanced Learner's Dictionary of Current English. $8^{\text {th }}$ edn, Oxford: Oxford University Press.

Jones, O. 2007. An ecology of emotion, memory, self and landscape. In: J. Davidson, L. Bondi, \& M. Smith (eds.), Emotional Geographies, 205-218. Aldershot, England; Burlington, VT: Ashgate.

Lockhart, Z. 2003. Fifth Born. New York: Washington Square Books.

Lockhart, Z. 2010. Fifth Born II: The Hundredth Turtle. Hillsborough, North Carolina: LaVenson Press.

McGuire, D. L. 2010. At the Dark End of the Street: Black Women, Rape, and Resistance: a New History of the Civil Rights Movement from Rosa Parks to the Rise of Black Power. New York: Vintage Books.

Olafson, E. 2004. Child sexual abuse. In: B. J. Cling (ed.), Sexualized Violence against Women and Children: A Psychology and Law Perspective, 151-87. New York: Guilford Press.

Ramsey, P. R. 1995. John A. Williams: the black American narrative and the city. In: Y. Hakutani \& R. Butler (eds.), The City in African-American Literature, 212-26. Madison: London; Cranbury, NJ: Fairleigh Dickinson University Press; Associated University Presses.

Russell, D. E. H. 1986. The Secret Trauma: Incest in the Lives of Girls and Women. New York: Basic Books.

Schama, S. 1995. Landscape and Memory. New York: A.A. Knopf: Random House.

Thien, D. 2007. Intimate distances: considering questions of 'us.' In: J. Davidson, L. Bondi, \& M. Smith (eds.), Emotional Geographies, 191-204. Aldershot, England; Burlington, VT: Ashgate. 
Whitehead, A. 2004. Trauma Fiction. Edinburgh: Edinburgh University Press.

$$
* * *
$$

Magdalena Lapińska is a graduate of the University of Białystok. She wrote her MA thesis on slavery-related traumatic experiences. Her primary area of academic interest is African American literature with its portrayals of violence and trauma. 